\title{
The Study of Soil Quality Indicators in Ibiono Ibom Area, Akwa Ibom State of Nigeria
}

\author{
Kamalu, Onyinyechi Jas. ${ }^{1}$ and Ndeh, Aniebiet Bassey $^{2}$ \\ Department of Crop and Soil Science \\ University of Port Harcourt
}

P.M.B. 5323 Port Harcourt, Rivers State, Nigeria

\begin{abstract}
Soil assessment of Ibiono Ibom area of Akwa Ibom State was carried out using morphological, physical and chemical properties. Undisturbed samples were collected using core cylinder samplers at different depths and disturbed samples were also collected from the genetic horizon of the soil profiles in Ikot Usen and Ibiaku Osuk areas. Soil profiles were described using the standard soil description in the USDA 1978/1999 system. Physical and chemical parameters were analyzed using the standard laboratory procedures. Data obtained from the study were analyzed and results showed that saturated hydraulic conductivity ranged from $0.00-89.10 \mathrm{~cm} / \mathrm{hr}$. Bulk density, particle density and total porosity ranged from $1.20-1.66 \mathrm{~g} / \mathrm{cm}^{3}, 1.50-3.07 \mathrm{~g} / \mathrm{cm}^{3}$ and $19.8-$ $56.7 \%$ respectively. Textures were generally sand to loamy sand. The impact of texture with bulk density and porosity enhances the performances of plants in the area and are indicative of moderate to high inherent soil quality. Most of the profiles have rapid permeability (mean of $17.03 \mathrm{~cm} / \mathrm{hr}$ and $48.88 \mathrm{~cm} / \mathrm{hr}$ ) and have relative greater potential to support roots. pH rating varied from extremely acid ( $\mathrm{pH} 4.3$ ) to moderately acid ( $\mathrm{pH}$ 5.7). Organic carbon content and total nitrogen were low having ranges of 0.0390 $-1.7356 \%$ and $0.01-0.14 \%$ respectively. The available phosphorus content ranged from $9.54-27.79 \mathrm{mg} / \mathrm{kg}$ and C: $\mathrm{N}$ ranged from 2 to 29. The implications of the narrow C:N ratios in some of the soils reflect high levels of microbial activity and rapid decomposition of organic matter with concomitant release of nutrient elements into soil solution for plant uptake.
\end{abstract}

Key words: Soil Quality Indicators, Critical Limits, Proper Management Approaches.

\section{INTRODUCTION}

Soil quality is defined as the capacity of a specific kind of soil to function within natural or managed ecosystem boundaries, to sustain plants and animals productivity, maintain or enhance water and air quality, and support human health and habitation [1]. According [2] soil quality is used when the purpose of soil is specified. [3] noted that between 1950 and 2000 over $25 \%$ of the 8.7 billion/ha of agricultural land, permanent pastures, forest and wood lands which are major sources of food, incomes and employment have been degraded with the largest being from developing countries. This according to [4] challenges the prospects for a better future of Africans and has potentials for increased conflicts over the next 25 to 30 years with obvious pressure on resources. To mitigate this, proper soil quality assessment is a necessity so as to meet the needs of the ever increasing global population. Proponents of soil quality argue that although soil scientists have long recognized the many unique and important properties and processes provided by fragile soil resources, outside the agricultural community, soils remain largely an undervalued resource [5]. Soil quality assessments are viewed as tools intended to alert users, in a manner analogous to a "consumer price index," that soil resource problems have or may be occurring.

Selection of key indicators and their critical limits which must be maintained for normal functioning of the soil are required to monitor changes and determine trends in improvement or deterioration in soil quality for various agro-ecological zones for use. Although, selection of soil indicators will vary with agro-ecological goals, the following seem to be suitable indicators for crop production in most cases; soil colour, soil texture, soil $\mathrm{pH}$, organic matter content, total nitrogen, available phosphorus, carbon nitrogen ratio, bulk density, total porosity and saturated hydraulic conductivity. This study aimed at assessment of these soil quality indicators in some areas of Ibiono Ibom through laboratory evaluation as well as comparison of the results with 
interpretation guide for evaluating analytical data with a view to making modest recommendation and proper management approaches of soils in the area.

\section{MATERIALS AND METHODS}

\subsection{The Study Area}

The study was carried out in Ikot Usen and Ibiaku Osuk areas in Ibiono Ibom Local Government Area of Akwa Ibom State, Nigeria (Fig. 1). Ibiono Ibom is bounded by Cross River State, Itu, Arochukwu (Abia State), Abak and Ini local government area. Ibiono Ibom occupies a land mass of 2761.76sq.km, with a total population of 385,145. It consists of 9 clans, 33 groups and 193 villages. It has coordinates; $5^{0} 14^{\prime} 0^{\prime} \mathrm{N} 7^{0} 53^{\prime} 0^{\prime} \mathrm{E} / 5.23333^{\circ} \mathrm{N} 7.88333^{0} \mathrm{E}$. The average temperature of the area is $25^{\circ} \mathrm{C}$ and the area witnesses two distinct seasons which are the dry and rainy seasons and has a number of rivers and tributaries flowing within its territory. The average humidity level of Ibiono Ibom is $85 \%$ while the wind speed is at an average of $10 \mathrm{~km} / \mathrm{h}$. The main ethnic group of Ibiono Ibom is the Ibibio people, who speak a dialect of the Ibibio language. The land use pattern of the area is in the order: agricultural, residential, transport, commercial and residential. Mineral resources include deposits of various stones, clay, sand and crude oil. There are forest resources such as palm trees, rubber, timber and others. The dwellers are predominantly farmers, traders and craftsmen.

\subsection{Sampling Techniques/ Data Collection}

Soils samples were collected from each horizon of the profiles sunk on two transect. Disturbed and undisturbed samples were collected from genetic horizons of the profiles and at different depths respectively. Soil profiles were described using the standard soil description in the USDA 1978/1999 system.

\subsection{Laboratory Analysis}

Saturated hydraulic conductivity was measured by the constant head perimeter technique as described [6]. Bulk density was determined by the core method described [7] where cores were dried to constant weight in an oven at a temperature of $105^{\circ} \mathrm{C}$. Total porosity was calculated with core samples [8]. Particle size analysis was done by hydrometer method modified [9]. The $\mathrm{pH}$ was determined in the laboratory using glass electrode $\mathrm{pH}$ meter. 1:1 soil to water ratio was used. Available Phosphorus was determined using Bray and Kurtz method [10]. Semi-micro Kjeldahl digestion method was used to determine Total Nitrogen. Total organic carbon was determined by the wet combustion method [11] as modified by Juo [9].

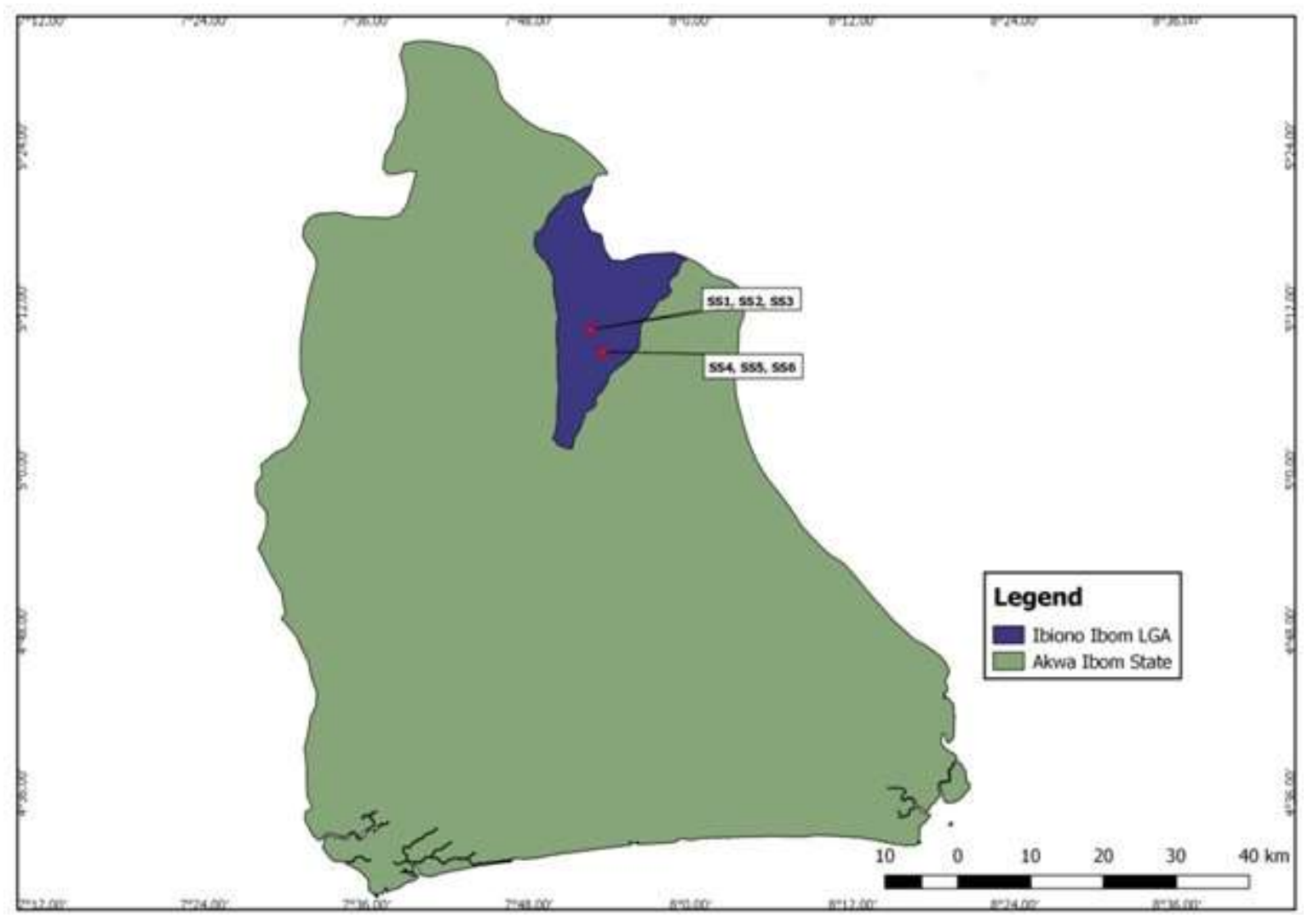

Figure 1: Map of Akwa Ibom State, showing the study area 


\section{RESULTS AND DISCUSSION}

\subsection{Morphological Properties and Soil Quality}

Detailed morphological features of the various profiles studied are presented in Table 1. The soils of Ibiono Ibom area are generally deep with four of the five profiles having effective depth of $200 \mathrm{~cm}$ and above. These deep profiles have no impermeable layer or depth to water table within $200 \mathrm{~cm}$. However, the shallowest effective depth was obtained in Ikot Usen 3 pedon with the effective depth of $47 \mathrm{~cm}$. The Ikot Usen 3 pedon was poorly drained and had relatively lower soil quality because it had ground water after the depth of $47 \mathrm{~cm}$. The genetic topsoil horizon in all the profiles were plow layer (Ap) and varied in depth from 0 $10 \mathrm{~cm}$ to $0-15 \mathrm{~cm}$ with exception of Ikot Usen 1 profile $(0-8 \mathrm{~cm})$ and $(0-5 \mathrm{~cm})$ for Ikot Usen 3 profile.

The colour at the surface horizons was predominantly very dark gray (7.5YR3/2) to very dark brown (10YR2/2) for Ikot Usen pedons and very dark gray (10YR3/1) to dark grayish brown (10YR4/2) for Ibiaku Osuk pedons. In these pedons throughout the soil matrix the hue rarely change by more than one hue column, showing the degree of uniformity in both parent material and other soil forming processes. The grayish colour of the horizon suggests low productivity. This is in line with the findings of [12][13].

The structure of the various horizons varied from medium crumb to fine crumb and fine granular at the surface. At the subsurface horizon the structure varied from fine angular blocky to medium angular blocky across the various pedons.

\subsection{Physical Properties of the Soils in the Study Area}

The physical properties of the soils in the pedons of the study areas are shown in Table 2 and Table 3 . The soils of Ibiono Ibom area are generally sandy (Table 3). This sandy nature can be attributed to the parent materials of the area, coastal plain sands [14]. The textural class predominant in Ibiono Ibom are sand and loamy sand. Sand content had a range of $(856-963 \mathrm{~g} / \mathrm{kg})$. Silt content ranges from $(60 \mathrm{~g} / \mathrm{kg}-86 \mathrm{~g} / \mathrm{kg})$ with the mean of $3.5 \%(35 \mathrm{~g} / \mathrm{kg})$. clay content ranges from $(26 \mathrm{~g} / \mathrm{kg}-98 \mathrm{~g} / \mathrm{kg})$. Though there was no definite trend, the clay content seems to increase with depth. This is because of the illuvial translocation of clay which is associated with rainfall pattern in the area. Particle density ranged between $1.50 \mathrm{~g} / \mathrm{cm}^{3}$ and $2.88 \mathrm{~g} / \mathrm{cm}^{3}$ within the pedons. Generally, particle density seems to be relatively lower on the surface. This agreed with the findings of [15] who attributed increasing particle density with soil depth to the inverse relation between organic matter and increasing soil depth.

According to [16], increase in bulk density may be due to lower organic matter content. Bulk density ranged between $1.20 \mathrm{~g} / \mathrm{cm}^{3}$ and $1.66 \mathrm{~g} / \mathrm{cm}^{3}$ in the soils of the Ibiono Ibom area. Surface horizons had low bulk density values in all the profiles which were closer to the ideal value of $1.3 \mathrm{~g} / \mathrm{cm}^{3}$. Generally, bulk density values increased with increase in depth of the profiles. This increase with depth may be due to compaction which resulted from over burden and less disturbance [17]. In comparison with the general relationship of soil bulk density to root growth based on soil texture [18], the bulk density values obtained in the area would not impair the ability of plant roots to penetrate the soils. 
International Journal of Advances in Scientific Research and Engineering (ijasre), Vol 7 (2), February -2021

Table 1: Morphological Features of the Soil Pedons in the Study Area

\begin{tabular}{|c|c|c|c|c|c|c|c|}
\hline \multicolumn{2}{|c|}{ Horizon Depth } & Colour (Moist) & Texture & Structure & Consistency & Boundary & Others \\
\hline \multicolumn{8}{|c|}{ Ikot Usen 1 (Summit, Cultivated land) } \\
\hline Ap & $0-8$ & $\begin{array}{c}\text { very dark gray } \\
(7.5 Y R 3 / 1)\end{array}$ & SL & 3 crumb & Very Fr & $\mathrm{cw}$ & $\mathrm{mfr}$, fmr, abundance of macro pores \\
\hline $\mathrm{AB}$ & $8-23$ & $\begin{array}{r}\text { strong brown } \\
(7.5 \mathrm{YR} 5 / 6)\end{array}$ & LS & $3 \mathrm{gr}$ & Fr & gw & mcr, abundance of macro pores \\
\hline B1t & $23-70$ & $\begin{array}{l}\text { strong brown } \\
(7.5 \text { YR5/6) }\end{array}$ & LS & 1ablk & $\mathrm{Fr}$ & gw & fcr, common macropores, activity of termites \\
\hline B2 & $70-130$ & $\begin{array}{l}\text { yellowish brown } \\
(10 Y R 5 / 6)\end{array}$ & SCL & 2ablk & $\mathrm{Fi}$ & gw & vfr, common micropores, hardness of layer \\
\hline B3 & $130-200$ & $\begin{array}{c}\text { reddish yellow } \\
(7.5 \mathrm{YR} 6 / 8)\end{array}$ & SCL & 3ablk & $\mathrm{Fi}$ & gw & $\mathrm{nr}$, abundance of micropores \\
\hline
\end{tabular}

Ikot Usen 2 (middle slope, Newly Harvested land)

\begin{tabular}{|c|c|c|c|c|c|c|c|}
\hline Ap & $0-15$ & $\begin{array}{c}\text { very dark gray } \\
(7.5 Y R 3 / 1)\end{array}$ & SL & 2 crumb & Very Fr & cs & $\mathrm{mfr}, \mathrm{fmr}$, abundance of macropores \\
\hline $\mathrm{AB}$ & $15-25$ & $\begin{array}{l}\text { dark reddish gray } \\
\quad(5 \mathrm{YR} 4 / 2)\end{array}$ & $\mathrm{LS}$ & $2 \mathrm{gr}$ & Very Fr & cs & mmr, abundance of macropores \\
\hline B1 & $25-65$ & $\begin{array}{l}\text { brown } \\
(7.5 \mathrm{YR} 4 / 2)\end{array}$ & LS & $3 \mathrm{gr}$ & $\mathrm{Fr}$ & $\mathrm{cw}$ & fmr, fcr, few macropores \\
\hline $\mathrm{B} 2$ & $65-103$ & $\begin{array}{l}\text { reddish yellow } \\
\quad(7.5 \mathrm{YR} 6 / 8)\end{array}$ & $\mathrm{LS}$ & 2ablk & Fr & gw & vfcr, common micropores \\
\hline B3t & $103-140$ & $\begin{array}{l}\text { reddish yellow } \\
(7.5 \mathrm{YR} 6 / 8)\end{array}$ & SCL & 3ablk & $\mathrm{Fi}$ & gw & vfr, abundance micropores \\
\hline $\mathrm{BC}$ & $140-200$ & $\begin{array}{l}\text { reddish yellow } \\
(7.5 \mathrm{YR} 6 / 8)\end{array}$ & SCL & 3ablk & $\mathrm{Fi}$ & gw & $\mathrm{nr}$, abundance of micropores \\
\hline
\end{tabular}

DOI: 10.31695/IJASRE.2021.33745 
International Journal of Advances in Scientific Research and Engineering (ijasre), Vol 7 (2), February -2021

\begin{tabular}{|c|c|c|c|c|c|c|c|}
\hline \multicolumn{8}{|c|}{ Ikot Usen 3 (Foot slope, fallow land) } \\
\hline Ap & $0-5$ & $\begin{array}{l}\text { very dark brown } \\
\quad(10 \mathrm{YR} 2 / 2)\end{array}$ & SL & $2 \mathrm{gr}$ & $\mathrm{Fr}$ & gs & $\mathrm{mfr}$, fmr, abundance macropores \\
\hline $\mathrm{AB}$ & $5-15$ & $\begin{array}{c}\text { very dark gray } \\
\text { (7.5YR3/1) }\end{array}$ & SCL & 2ablk & Slightly St & gw & mmr, common macropores, wettness \\
\hline B1t & $15-47$ & brown $(7.5 \mathrm{YR} 5 / 4)$ & SCL & 3ablk & St & gw & fmr, wetness \\
\hline B2 & $47-110$ & $\begin{array}{l}\text { yellowish brown } \\
\text { (10YR5/8) }\end{array}$ & $\mathrm{C}$ & 3ablk & very $\mathrm{St}$ & gw & cvfr, water table \\
\hline
\end{tabular}

Horizon Depth Colour (Moist) $\quad$ Texture Structure Consistency Boundary Others Ibiaku Osuk 1 (Middle slope, Cultivated land )

\begin{tabular}{|c|c|c|c|c|c|c|c|}
\hline Ap & $0-10$ & $\begin{array}{l}\text { dark gray } \\
(10 \text { YR4/1) }\end{array}$ & SL & 3 crumb & very Fr & cs & $\mathrm{mfr}$, fmr, abund ance of macropores \\
\hline $\mathrm{AB}$ & $10-39$ & $\begin{array}{l}\text { very dark gray } \\
(10 \mathrm{YR} 3 / 1)\end{array}$ & LS & $2 \mathrm{gr}$ & very Fr & cs & $\mathrm{mmr}$, ffr, abundances of pores \\
\hline B1 & $39-60$ & $\begin{array}{l}\text { yellowish brown } \\
(10 \text { YR5/6) }\end{array}$ & LS & 2ablk & Fr & $\mathrm{cw}$ & $\mathrm{ccr}$, common macropores \\
\hline B2 & $60-110$ & $\begin{array}{l}\text { yellowish brown } \\
(10 \text { YR5/6) }\end{array}$ & LS & 3ablk & Fr & gw & fcr, more of micrpores \\
\hline B3 & $110-200$ & reddish yellow & LS & 3ablk & $\mathrm{Fi}$ & $\mathrm{gw}$ & no root, abundance of micropores \\
\hline
\end{tabular}

\section{Ibiaku Osuk 2 (Foot slope, Fallowed Land)}

\begin{tabular}{|c|c|c|c|c|c|c|c|}
\hline Ap & $0-10$ & $\begin{array}{l}\text { dark greyish brown } \\
\quad(10 \mathrm{YR} 4 / 2)\end{array}$ & SL & $2 \mathrm{gr}$ & very $\mathrm{Fr}$ & cs & $\mathrm{mfr}$, fmr, abundance of macropores \\
\hline $\mathrm{AB}$ & $10-30$ & $\begin{array}{l}\text { dark greyish brown } \\
(10 \mathrm{YR} 4 / 2)\end{array}$ & LS & $2 \mathrm{gr}$ & $\mathrm{Fr}$ & gs & mmr, ffr, common macropores \\
\hline B1 & $30-63$ & $\begin{array}{l}\text { very dark greyish } \\
\text { brown (10YR3/2) }\end{array}$ & LS & $3 g r$ & $\mathrm{Fr}$ & gw & mcr, abundance macropores \\
\hline B2 & $63-115$ & $\begin{array}{l}\text { dark greyish brown } \\
\quad(10 \mathrm{YR} 4 / 2)\end{array}$ & $\mathrm{LS}$ & 2ablk & $\mathrm{Fr}$ & gw & fmr, more of mesopores, activity of rodents \\
\hline B3t & $115-168$ & reddish yellow & LS & 2ablk & $\mathrm{Fi}$ & $\mathrm{cw}$ & fmr, white gravels. \\
\hline
\end{tabular}

DOI: 10.31695/IJASRE.2021.33745 
International Journal of Advances in Scientific Research and Engineering (ijasre), Vol 7 (2), February -2021

BC $168-200 \begin{gathered}(7.5 \text { YR6/8) } \\ \begin{array}{c}\text { reddish yellow } \\ (7.5 Y R 6 / 8)\end{array}\end{gathered} \quad$ LS $\quad$ 2ablk $\quad$ Fr $\quad$ gw $\quad$ nr, dark reddish brown stones and white gravels

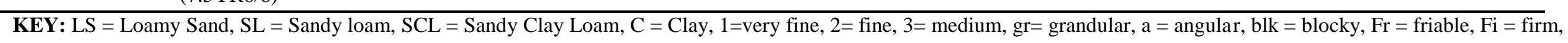

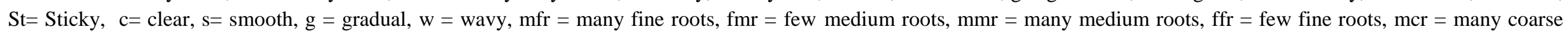

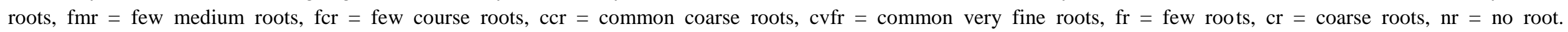

DOI: 10.31695/IJASRE.2021.33745 
The total porosity of the soils ranges from $19.8 \%-56.7 \%$ (Table 2). All the profiles had low total porosity value between 19.8 $31.6 \%$ at the Ap horizon $(0-20 \mathrm{~cm})$ with the exception of Ibiaku Osuk 2 profile which had the total porosity of $56.7 \%$ at the surface horizon. These low values are possibly due to the values of bulk densities. These soils are easily eroded due to this low total porosity under rainfall. Similarly, flooding and erosion risk of some soils of the Ogba- Egbema area to low total porosity[19].

Soil bulk density, soil porosity and particle density enable the degree of compaction and aeration of the soil[19]. The combining impact of the predominantly sand to loamy sand texture with bulk density and porosity further enhances the performances of plants in the area and are indicative of moderate to high inherent soil quality.

Data for saturated hydraulic conductivity presented in Table 2 showed a wide range of $0-94.72 \mathrm{~cm} / \mathrm{hr}$. Water movement through sands is very rapid under saturated conditions and slow under unsaturated conditions. This can be attributed to pore size distribution and moisture retention capacity. This study shows that the infiltration of water into the soil is high, low availability of water to plant roots and high leaching losses ranges is likely to occur at the Ikot Usen 1 soil whose permeability class show very rapid. The Ikot Usen 2 and Ikot Usen 3 soils permeability classes (extremely slow after $20 \mathrm{~cm}$ and $40 \mathrm{~cm}$ depth respectively) is an indication of root penetration restriction. The Ibiaku Osuk 1 and Ibiaku Osuk 2 profiles have rapid permeability generally with mean of $17.03 \mathrm{~cm} / \mathrm{hr}$ and $48.88 \mathrm{~cm} / \mathrm{hr}$ respectively. This implies that The Ibiaku Osuk 1 and Ibiaku Osuk 2 soils are well drained and have relative greater potential to support roots.

Table 2: Bulk Density, Particle density, Total Porosity and Hydraulic Conductivity of the Soils

\begin{tabular}{cccccl}
\hline $\begin{array}{c}\text { Location Depth } \\
(\mathbf{c m})\end{array}$ & $\begin{array}{c}\text { Bulk Density } \\
\left(\mathbf{g} / \mathbf{c m}^{\mathbf{3}}\right)\end{array}$ & $\begin{array}{c}\text { Particle density } \\
\mathbf{g} / \mathbf{c m}^{\mathbf{3}}\end{array}$ & $\begin{array}{c}\text { Total porosity } \\
(\mathbf{\%})\end{array}$ & $\begin{array}{c}\text { Ksat. } \\
(\mathbf{c m} / \mathbf{h r})\end{array}$ & $\begin{array}{c}\text { Permeability } \\
\text { Class }\end{array}$ \\
\hline IKOT USEN 1 (Summit, Cultivated Land) & & & & & \\
$0-10$ & 1.20 & 1.50 & 19.8 & 89.10 & Very rapid \\
$10-40$ & 1.22 & 1.70 & 28.4 & 76.64 & Very rapid \\
$40-60$ & 1.26 & 2.04 & 38.1 & 43.53 & Rapid \\
$60-80$ & 1.43 & 2.46 & 42.0 & 28.36 & Rapid \\
Mean & 1.28 & 1.93 & 32.1 & 59.41 &
\end{tabular}

IKOT USEN 2 (Middle Slope, Newly Harvested Farmland)

$\begin{array}{cccccc}0-20 & 1.23 & 1.83 & 32.4 & 38.61 & \text { Rapid } \\ 20-40 & 1.66 & 2.71 & 38.7 & 0.00 & \text { Extremely slow } \\ 40-60 & 1.50 & 2.35 & 36.3 & 5.35 & \text { Moderately slow } \\ 60-80 & 1.53 & 2.67 & 40.5 & 0.00 & \text { Extremely slow } \\ \text { Mean } & 1.48 & 2.39 & 36.9 & 10.99 & \end{array}$

IKOT USEN 3 (Foot Slope, Fallowed Land)

$\begin{array}{crrrrl}0-20 & 1.36 & 1.92 & 29.3 & 42.01 & \text { Rapid } \\ 20-40 & 1.21 & 2.48 & 51.1 & 41.72 & \text { Rapid } \\ 40-60 & 1.33 & 3.07 & 56.7 & 0.00 & \text { Extremely slow } \\ 60-80 & 1.45 & 2.88 & 49.6 & 0.00 & \text { Extremely slow } \\ \text { Mean } & 1.34 & 2.59 & 46.7 & 20.93 & \end{array}$

IBIAKU OSUK 1 (Middle Slope, Cultivated Farmland)

\begin{tabular}{|c|c|c|c|c|c|}
\hline $0-10$ & 1.42 & 2.07 & 31.6 & 50.72 & Rapid \\
\hline $10-35$ & 1.63 & 2.44 & 33.1 & 9.84 & Moderately rapid \\
\hline $35-55$ & 1.64 & 2.25 & 26.7 & 2.90 & Moderate \\
\hline $55-75$ & 1.66 & 2.42 & 31.3 & 4.66 & Moderate \\
\hline Mean & 1.59 & 2.30 & 30.7 & 17.03 & \\
\hline
\end{tabular}


Table 3: Particle Size Distribution

\begin{tabular}{|c|c|c|c|c|c|}
\hline $\begin{array}{l}\text { Location/ } \\
\text { Horizons }\end{array}$ & $\operatorname{Depth}(\mathrm{cm})$ & \%Sand & \%Silt & $\%$ Clay & Textural Class \\
\hline
\end{tabular}

IKOT USEN 1 (Summit, Cultivated Land)

$\begin{array}{lccccl}\text { Ap } & 0-8 & 94.6 & 2.6 & 2.8 & \text { Sand } \\ \text { AB } & 8-23 & 93.9 & 2.3 & 3.8 & \text { Sand } \\ \text { B1t } & 23-70 & 90.9 & 1.0 & 8.1 & \text { Sand } \\ \text { B2 } & 70-130 & 90.6 & 3.6 & 5.8 & \text { Sand } \\ \text { B3 } & 130-200 & 89.6 & 4.3 & 6.1 & \text { Loamy sand } \\ & \text { Mean } & \mathbf{9 1 . 9} & \mathbf{2 . 8} & \mathbf{5 . 3} & \end{array}$

IKOT USEN 2 (Middle Slope, Newly Harvested Farmland)

$\begin{array}{lccccl}\text { Ap } & 0-15 & 93.6 & 3.8 & 2.6 & \text { Sand } \\ \text { AB } & 15-25 & 93.6 & 3.4 & 3.0 & \text { Sand } \\ \text { B1 } & 25-65 & 94.6 & 2.6 & 2.8 & \text { Sand } \\ \text { B2 } & 65-103 & 90.6 & 2.6 & 6.8 & \text { Sand } \\ \text { B3t } & 103-140 & 87.6 & 2.6 & 9.8 & \text { Loamy sand } \\ \text { BC } & 140-200 & 86.9 & 8.3 & 4.8 & \text { Loamy sand } \\ & \text { Mean } & \mathbf{9 1 . 1} & \mathbf{3 . 9} & \mathbf{5 . 0} & \end{array}$

IKOT USEN 3 (Foot Slope, Fallowed Land)

$\begin{array}{llllll}\text { Ap } & 0-5 & 94.9 & 2.6 & 2.5 & \text { Sand } \\ \text { AB } & 5-15 & 92.9 & 4.5 & 2.6 & \text { Sand } \\ \text { B1t } & 15-47 & 85.9 & 4.3 & 9.8 & \text { Loamy sand } \\ \text { B2 } & 47-110 & 85.6 & 8.6 & 5.8 & \text { Loamy sand } \\ & \text { Mean } & \mathbf{8 9 . 8} & \mathbf{5 . 0} & \mathbf{5 . 2} & \end{array}$

IBIAKU OSUK 1 (Middle Slope, Cultivated Land)

\begin{tabular}{llllll} 
Ap & $0-10$ & 93.3 & 3.3 & 3.4 & Sand \\
AB & $10-39$ & 90.3 & 4.3 & 5.4 & Sand \\
B1 & $39-60$ & 90.3 & 5.3 & 4.4 & Sand \\
B2 & $60-110$ & 89.3 & 4.3 & 6.4 & Loamy sand \\
\hline
\end{tabular}


International Journal of Advances in Scientific Research and Engineering (ijasre), Vol 7 (2), February -2021

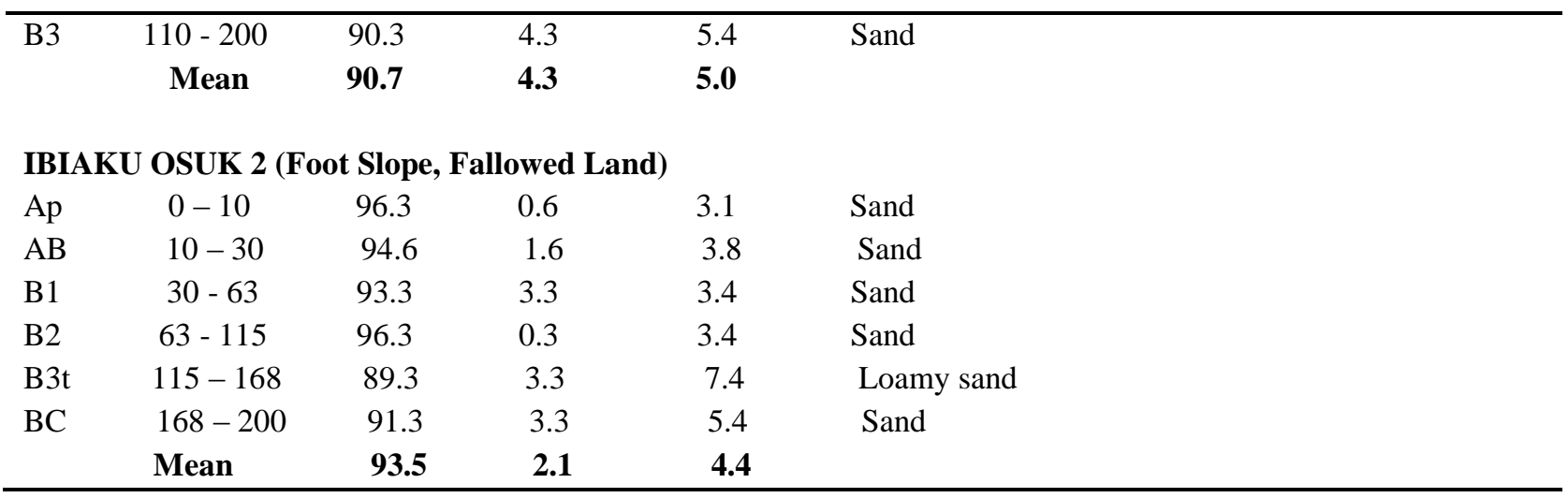

\subsection{Soil Reaction $(\mathrm{pH})$}

The results in Table 4, indicate that the soils' $\mathrm{pH}$ rating varied from moderately acid to extremely acid. There was no definite trend of the $\mathrm{pH}$ values with regards to depth. Therefore this disagreed with the observation of Esu [21], who reported a general decrease in $\mathrm{pH}$ values with increase in depth. The top soils of Ikot Usen 1 and Ikot Usen 2 indicate very strongly acid while that of Ibiaku Osuk 1 and Ibiaku Osuk 2 indicate strongly acid. Hence, soil nutrients especially Phosphorus, Nitrogen, sulphur and some micronutrients are affected [22]. Similarly, it was reported that soil $\mathrm{pH}$ influences nutrient availability in the soil and Manganese (Mn) are increased with acidity while the availability of macronutrients (N,P, K and $\mathrm{S}$ ) are reduced resulting to deficiency symptoms in some plants growing on such soils[23]. The acidic nature of Ibiono Ibom soils can be attributed to the texture of the soil and high rainfall, were elements are highly leached leading to acidity. This observation conforms to that of Chiekezie et al. [24].

\subsection{Total Organic Carbon (TOC)}

The data for total organic carbon is presented in Table 4, indicate a general decrease of TOC with depth in all the profiles. Considering the Critical limits of interpreting levels of analytical parameters [25] in Table 4, the soils of the study area had low organic carbon content. The low organic carbon of the area can be attributed to continuous cropping, as well as annual slash and burn system of farming which discourages the build-up of organic matter status. These practices results in low organic matter and impaired chemical soil quality and low agricultural yield in soils of the area [26].

\subsection{Total Nitrogen}

Generally, total nitrogen ranged between $0.01-0.14 \%$. There was a definite trend in the values of the total nitrogen, hence, the decrease in the values of total nitrogen with increase in depth. Following the rating of total $\mathrm{N}$ of $>1 \%$ as very high, $0.5-1 \%$ as high, $0.2-0.5 \%$ as medium, $0.1-0.2 \%$ as low and $<0.1 \%$ as very low Nitrogen status as indicated by Landon [27], the surface soils of Ikot Usen 1 and Ikot Usen 3 qualify for low Nitrogen status while others qualify for very low status of Nitrogen.

From the result, low nitrogen is a limiting factor to sustainable agricultural productivity of the area [19]. Hence, resulting in the low yield from farms in the area. This can be associated to the farming system practiced in the area where organic wastes inputs is not sufficiently incorporated into the soil [28].

\subsection{Carbon-Nitrogen Ratio}

Carbon-Nitrogen Ratio is written as C:N and is usually a single number [29]. It is defined as the ratio of the weight of organic carbon to the weight of total nitrogen in a soil or organic matter. It is the relationship between organic matter and nitrogen content of soils. C:N of the sampling stations ranges from 06 to 29 as shown in table 10. Ibiaku Osuk 1 pedon had the lowest value with the mean value of 17 while Ikot Usen 1 soil had the highest value with the mean of 19. The implications of the narrow C:N ratios in some of the soils as shown in Table (4) reflect high levels of microbial activity and rapid decomposition of organic matter with concomitant release of nutrient elements into soil solution for plant uptake. This conforms to the observation of Akpan-Idiok [30]. 


\subsection{Available Phosphorus}

Generally, the available phosphorus of the soils in Ibiono Ibom area ranges from $9.54 \mathrm{mg} / \mathrm{kg}-27.79 \mathrm{mg} / \mathrm{kg}$ (Table 4). In Ikot Usen 1 soil the range was $12.35 \mathrm{mg} / \mathrm{kg}-27.79 \mathrm{mg} / \mathrm{kg}$, Ikot Usen 2 soil had $10.12-19.65 \mathrm{mg} / \mathrm{kg}$, the range of Ikot Usen 3 soil was $9.54-$ $18.25 \mathrm{mg} / \mathrm{kg}$, the Ibiaku Osuk 1 had the range $11.79-23.02 \mathrm{mg} / \mathrm{kg}$, Ibiaku Osuk 2 ranges from $10.12-24.70 \mathrm{mg} / \mathrm{kg}$ and Ibiaku Osuk 2 ranges from $14.04-26.95 \mathrm{mg} / \mathrm{kg}$. Following the critical levels according to Esu [25], the available $\mathrm{P}$ is medium to high in Ikot Usen 1 soil, Ibiaku Osuk 1 soil and Ibiaku Osuk 2 while at Ikot Usen 2 the critical level of the available P is medium and low to medium at Ikot Usen 3 soils. 
Table 4: Some Chemical Indicator Ratings of the Soils in the Study Area

\begin{tabular}{|c|c|c|c|c|c|c|c|c|c|}
\hline $\begin{array}{l}\begin{array}{l}\text { Location Depth } \\
\text { Horizon }(\mathrm{cm})\end{array}\end{array}$ & pH value & Rating & $\begin{array}{r}\text { TOC } \\
(\%)\end{array}$ & Rating & $\begin{array}{c}\text { Total N } \\
(\%)\end{array}$ & Rating & $\mathrm{C}: \mathbf{N}$ & Avail. P & Rating \\
\hline
\end{tabular}

IKOT USEN 1 (Summit, Cultivated Land)

$\begin{array}{lllllllllll}\text { Ap } & 0-8 & 4.5 & \text { Very strongly acid } & 1.7355 & \text { High } & 0.11 & \text { Low } & 16 & 17.40 & \text { Medium } \\ \text { AB } & 8-23 & 4.3 & \text { Extremely acid } & 0.8775 & \text { Low } & 0.05 & \text { Very low } & 18 & 12.35 & \text { Medium } \\ \text { B1t } & 23-70 & 4.3 & \text { Extremely acid } & 0.3705 & \text { Very low } & 0.02 & \text { Very low } & 19 & 27.79 & \text { High } \\ \text { B2 } & 70-130 & 4.3 & \text { Extremely acid } & 0.6825 & \text { Low } & 0.03 & \text { Very low } & 23 & 19.65 & \text { Medium } \\ \text { B3 } & 130-200 & 5.1 & \text { Strongly acid } & 0.2145 & \text { Very low } & 0.01 & \text { Very low } & 22 & 12.35 & \text { Medium } \\ & \text { Mean } & & & \mathbf{0 . 7 7 6 1} & & \mathbf{0 . 0 4} & & \mathbf{1 9} & \mathbf{1 7 . 9 1} & \end{array}$

IKOT USEN 2 (Middle Slope, Newly Harvested Farmland)

\begin{tabular}{|c|c|c|c|c|c|c|c|c|c|c|}
\hline Ap & $0-15$ & 4.9 & Very strongly acid & 1.4625 & Moderate & 0.10 & Low & 16 & 11.79 & Medium \\
\hline $\mathrm{AB}$ & $15-25$ & 4.4 & Extremely acid & 1.1115 & Moderate & 0.10 & Low & 12 & 12.35 & Medium \\
\hline B1 & $25-65$ & 4.6 & Very strongly acid & 0.9945 & Low & 0.05 & Very low & 20 & 14.04 & Medium \\
\hline B2 & $65-103$ & 4.9 & Very strongly acid & 0.4875 & Low & 0.02 & Very low & 24 & 14.04 & Medium \\
\hline B3t & $103-140$ & 4.8 & Very strongly acid & 0.6240 & Low & 0.03 & Very low & 21 & 19.65 & Medium \\
\hline \multirow[t]{2}{*}{$\mathrm{BC}$} & $140-200$ & 5.3 & Strongly acid & 0.2145 & Very low & 0.02 & Very low & 11 & 10.12 & Medium \\
\hline & Mean & & & 0.8158 & & 0.05 & & 17 & 13.67 & \\
\hline \multicolumn{11}{|c|}{ IKOT USEN 3 (Foot Slope, Fallowed Land) } \\
\hline Ap & $0-5$ & 5.7 & Moderately acid & 2.4960 & Very High & 0.14 & Low & 18 & 11.23 & Medium \\
\hline $\mathrm{AB}$ & $5-15$ & 5.1 & Strongly acid & 1.2285 & Moderate & 0.07 & Very low & 18 & 9.54 & Low \\
\hline B1t & $15-47$ & 4.7 & Very strongly acid & 0.7215 & Low & 0.05 & Very low & 14 & 14.04 & Medium \\
\hline \multirow[t]{2}{*}{ B2 } & $47-110$ & 4.6 & Very strongly acid & 0.8775 & Low & 0.05 & Very low & 18 & 18.25 & Medium \\
\hline & Mean & & & 1.3309 & & 0.08 & & 17 & 13.27 & \\
\hline
\end{tabular}

DOI: 10.31695/IJASRE.2021.33745 
International Journal of Advances in Scientific Research and Engineering (ijasre), Vol 7 (2), February -2021

\begin{tabular}{|c|c|c|c|c|c|c|c|c|c|}
\hline $\begin{array}{l}\begin{array}{l}\text { Location Depth } \\
\text { Horizon (cm) }\end{array} \\
\end{array}$ & pH value & Rating & $\begin{array}{l}\text { TOC } \\
(\%)\end{array}$ & Rating & $\begin{array}{c}\text { Total N } \\
(\%)\end{array}$ & Rating & $\mathrm{C:N}$ & Avail. $P$ & Rating \\
\hline \multicolumn{10}{|c|}{ IBIAKU OSUK 1 (Middle Slope, Cultivated Land) } \\
\hline $0-10$ & 5.5 & Strongly acid & 0.7605 & Low & 0.05 & Very low & 15 & 21.33 & High \\
\hline $10-39$ & 5.5 & Strongly acid & 0.6240 & Low & 0.03 & Very low & 21 & 10.12 & Medium \\
\hline $39-60$ & 5.1 & Strongly acid & 0.2925 & Very low & 0.01 & Very low & 29 & 19.65 & Medium \\
\hline $60-110$ & 5.3 & Strongly acid & 0.1365 & Very low & 0.01 & Very low & 14 & 24.70 & High \\
\hline $110-200$ & 5.6 & Moderately acid & 0.0585 & Very low & 0.01 & Very low & 06 & 18.53 & Medium \\
\hline Mean & & & 0.3744 & & 0.02 & & 17 & 18.87 & \\
\hline
\end{tabular}

IBIAKU OSUK 2 (Foot Slope, Fallowed Land)

$\begin{array}{lllllllllll}\text { Ap } & 0-10 & 5.2 & \text { Strongly acid } & 1.4820 & \text { Moderate } & 0.10 & \text { Low } & 17 & 15.99 & \text { Medium } \\ \text { AB } & 10-30 & 4.8 & \text { Very strongly acid } & 1.3065 & \text { Moderate } & 0.10 & \text { Low } & 16 & 14.04 & \text { Medium } \\ \text { B1 } & 30-63 & 4.9 & \text { Very strongly acid } & 0.9555 & \text { Low } & 0.05 & \text { Very low } & 19 & 14.04 & \text { Medium } \\ \text { B2 } & 63-115 & 5.3 & \text { Strongly acid } & 0.4290 & \text { Low } & 0.03 & \text { Very low } & 14 & 14.04 & \text { Medium } \\ \text { B3t } & 115-168 & 5.2 & \text { Strongly acid } & 0.1755 & \text { Very low } & 0.01 & \text { Very low } & 18 & 26.95 & \text { High } \\ \text { BC } & 168-200 & 5.5 & \text { Strongly acid } & 0.1505 & \text { Very low } & 0.01 & \text { Very low } & 14 & 14.04 & \text { Medium } \\ & \text { Mean } & & & \mathbf{0 . 9 1 6 5} & & \mathbf{0 . 0 6} & & \mathbf{1 6} & \mathbf{1 6 . 5 2} & \end{array}$

[Source of Rating [25][31]

TOC $=$ Total Organic Carbon, $\mathrm{N}=$ Nitrogen, $\mathrm{P}=$ Phosphorus, $\mathrm{C}: \mathrm{N}=$ Carbon - Nitrogen Ratio 
International Journal of Advances in Scientific Research and Engineering (ijasre), Vol 7 (2), February -2021

\section{CONCLUSIONS}

Generally, most of the soils of Ibiono Ibom area have excellent physical conditions which includes; it well drained nature, although the chemical condition is poor. The indicators range varied considerably from very low to high. Saturated hydraulic conductivity ranged from $0.00-89.10 \mathrm{~cm} / \mathrm{hr}$. Bulk density, particle density and total porosity ranged from $1.20-1.66 \mathrm{~g} / \mathrm{cm}^{3}, 1.50-3.07 \mathrm{~g} / \mathrm{cm}^{3}$ and $19.8-56.7 \%$ respectively. Textures were generally sand to loamy sand, TOC and TN varied from very low to high generally, while other indicators such as available P. varied from medium to high. The low organic carbon and Nitrogen of the area can be attributed to continuous cropping, as well as annual slash and burn system of farming which discourages the build-up of organic matter. These practices result in low organic matter and impaired chemical soil quality and low agricultural yield in soils of the area. Based on the results of this study, soils within Ikot Usen 1, Ibiaku Osuk pedons are more suitable for agriculture than soils within Ikot Usen 2 and 3 pedons.

\section{REFERENCES}

1. Karlen, D. L.; Mausbach, M. J.; Doran, J.W.; Cline, R.G.; Harris, R.F. and Schuman, G.E. (1997). Soil quality: a concept, definition, and framework for evaluation. Soil Science Society of America Journal, 61:4-10.

2. Doran J. W. and Jones A. J. (1996). Methods for Assessing Soil Quality. SSSA, Special Publication Number 49; Soil Science Society of America 667 South Segoe Rd Madison W153711 USA.

3. Soomro, G. H. (2006). Desertification; Causes, Consequencies and Remedies. AGRIS Volume :22 (1), Pp: 44 -51.

4. Glaser, B. (2007). Prehistorically Modified Soil of Central Amazonia, a Model for Sustainable Agriculture in the twenty-first century: Philtrans R., SOC B 362; 187-196.

5. Karlen, D. L., Ditzler, C. A., and Andrews, S.S. (2003). Soil quality: why and how? Geoderma, 114(3-4), 145-156.

6. Klute, A. and Dirksen, C. (1986). Hydraulic Conductivity and Diffusivity, Laboratory Methods in: Klute, A.(eds), Methods of Soil Analysis. Part1 and 2nd ed., ASA and SSSA. Madison WI; Pp. 425 - 442.

7. Blake, G. R. and Hartage, K. H. (1986). Bulk density and Perticle Density. In: Methods of Soil Analysis Part 1. Agronomy Monograph 9. (Ed. A. Klute) (ASA and SSSA: Madison, WI) 363 - 382.

8. Flint. L. E. and Flint, A. L. (2002). Pore Size Distribution. In: Methods of Soil Analysis. Part1. Physical Methods. Done, J. H., and Topp, G. C. (Eds). Soil Science Society of America, Madison. WI: 246-253.

9. Juo, A. S. R. (1979). Selected Methods of Soil and Plant Analysis. IITA, Manual Series No.1, 70p.

10. Bray, R. H. and Kurtz, L. T. (1945). Determination of Total Nitrogen and Available Forms of Phosphosrus in Soils. Soil Scienc, 59: $39-45$.

11. Walkley, A. and Black. I. A. (1934). An Examination of Degtjareff Method of Determining Soil Organic Matter and a proposed Modification of the Chromic Acid Titration Method. Soil Science, 37, 29-37.

12. Obasi, S. N. (2010). Classification and Suitability of Selected Soils of a Amasiri, Ebonyi State: A Geographical Information System Approach. Unpublished MSc. Thesis, Soil Science Department, Federal University of Technology, Owerri.

13. Kamalu, O. J., Anozie, H. I and Ovat, N. (2018). Morphological Characterization and Soil Quality Assessment Along a Toposequence in Obubra Cross River State, Nigeria. New York Science Journal; 11(6).

14. Akamigbo, F. O. R. (2000). Nigerian Agriculture and Challenges of the $21^{\text {st }}$ Century: Nigerian Soils. Agro. Sci. J. of Trop. Vol.1(1).

15. Ahmed, H. (2002). Assessment of Spatial Variability of some Physicochemical Properties of Soils under Different Elevations and Land Use Systems in the Western Slopes of Mount Chilalo, Arsi. M.Sc. Thesis Submitted to the School of Graduate Studies, Alemaya University, Ethiopia. 111.

16. Ojimgba, O. and Mbagwu, J.S.C. (2007). Evaluation of physical and chemical properties of an eroded Ultisol and their effects on maize yield. Journal of Science, Agriculture, Food Technology and the Environment. Vol.7.No.1.Pp.57-64. Faculty of Agriculture, Ebonyi State University, Abakaliki, Nigeria. 


\section{International Journal of Advances in Scientific Research and Engineering (ijasre), Vol 7 (2), February -2021}

17. Brady, R.H and Weil, R. (2002). The Nature and Properties of Soils. 13th edition, Singapore, Pearson Education, 976.

18. Doran, J. W. and Jones, K. P. (2011). General Relationship of Soil Bulk Density to Plant Growth Based on Soil Texture. Soil Science Society America., Madison, Winsconsin, p.610.

19. Kamalu, O. J., Udom, B. E. and Omenihu, A. A. (2017). Assessment of Soil Quality in Representative Pedons of the Sombreiro Warri Deltaic Plain of the Niger Delta, Nigeria. International Journal of Agriculture and Earth Science Vol. 3 No. 5 ISSN 24890081

20. Soil Survey Staff. (1993). Soil Conservation Service, National Soil Survey Handbook, Section 618.35, U.S. Government Office, Washington, DC.

21. Esu, I. E. (2010). Soil Characterization and Mapping for Food Security and Sustainable Environment in Nigeria. Proceedings of 29th Annual Conference.

22. Agbede, O. O. (2009). Understanding Soil and Plant Nutrition. 1st Edition, Keffi-Nasarawa State, Salman Press \& Co. Nigeria Ltd. 260pp.

23. Onweremadu, E. U; Okuwa, J. A. and Ufot, U. O. (2011). Nitrogen forms distribution in isohyperthermic Kandi adults of Central Southeastern Nigeria. Nigerian Journal of Agriculture, Food and Environment. 7(2): 52 - 56.

24. Chiekezie, I. A., Eswaran, H., Asawalam D.O. and Ano, A. O. (2010). Characterization of two benchmark soils of contrasting parent materials in Abia State, Southeastern Nigeria. Global Journal of Pure and Applied Science., 16:23-29.

25. Esu, I. E. (1991). Detailed Soil Survey of NIHORT Farm at Bunkure, Kano State, Nigeria. Institute for Agricultural Research, Ahmadu Bello University, Zaria, Nigeria.

26. Yihenew G. (2002). Selected Chemical and Physical Characteristics of Soils, Adet Research Center and its Testing Sites in NorthWestern Ethopia. Ethopian Journal of National Resources. 4(2):199-215

27. Landon, J.R. (1991). Booker Tropical Soil Manual: A Handbook for Soil Survey and Agricultural Land Evaluation in the Tropics and Subtropics. Longman Scientific and Technical, Essex, New York. 474p.

28. Mulugeta Lemenih (2004). Effects of Land Use Changes on Soil Quality and Native Flora Degradation and Restoration in the Highlands of Ethopia: IImplication for Sustainable Land Management. PhD Thesis Presented to Swedish University of Agricultural Science, Uppsala.

29. Flavel, T. C and Murphy G. H.(2006). Carbon and Nitrogen Mineralization Rates after Application of Organic Amendments to Soil. Journal of Enivironmental Quality.

30. Akpan-Idiok, A.U. (2012). Physicochemical Properties, Degradation Rate and Vulnerability Potential of Soils Formed on Coastal Plain Sands in Southeast, Nigeria. International Journal of Agricultural Research. 7(7): 358-366.

31. Metson, A. J. (1961). Methods of Chemical Analysis of Soil Survey Samples. Govt., Printers Wellington, New Zealand. Journal of Soil Science and Environment. Pp. 64. 